\title{
Importance of bacterivory by pigmented and heterotrophic nanoflagellates during the warm season in a subtropical western Pacific coastal ecosystem
}

\author{
An-Yi Tsai ${ }^{1}$, Gwo-Ching Gong ${ }^{1}$, Robert W. Sanders ${ }^{3}$, Wei-Hung Chen ${ }^{2}$, \\ Chien-Fu Chao ${ }^{2}$, Kuo-Ping Chiang ${ }^{1,2, *}$
}

${ }^{1}$ Institute of Marine Environmental Chemistry and Ecology and ${ }^{2}$ Institute of Environmental Biology and Fishery Science, National Taiwan Ocean University, Keelung 202-24, Taiwan, ROC

${ }^{3}$ Department of Biology, Temple University, Philadelphia, Pennsylvania 19122, USA

\begin{abstract}
We investigated temporal variations in the effects of bacterivory by different sizes of heterotrophic nanoflagellates (HNF) and pigmented nanoflagellates (PNF) during a warm period (May to September) in oligotrophic coastal waters of the subtropical western Pacific. Short-term experiments with fluorescently labeled bacteria (FLB) demonstrated ingestion rates of 0.3 to 5.8 bacteria $\mathrm{HNF}^{-1} \mathrm{~h}^{-1}$ by HNF in the size range $3-6 \mu \mathrm{m}$-rates that were higher than observed for other sizes of HNF. Rates of ingestion by PNF ranged between 0.9 and 15.5 cells $\mathrm{PNF}^{-1} \mathrm{~h}^{-1}$, and, as for HNF, were greatest for PNF in the 3-6 $\mu \mathrm{m}$ size group. Nanoflagellates of size $<6 \mu \mathrm{m}$ removed about $98 \%$ of the total amount of bacteria consumed. The 3-6 $\mu \mathrm{m}$ PNF, 2-3 $\mu \mathrm{m}$ HNF, and 3-6 $\mu \mathrm{m}$ HNF were major consumers in the nanoflagellate community and were responsible for an average of 52, 28 and $16 \%$ of the total consumption of bacteria, respectively. The smallest PNF $(2-3 \mu \mathrm{m})$ consumed only about $2 \%$ of the total and were considered to be primarily autotrophic. Despite ingestion rates in the range of those reported elsewhere, the low abundance of nanoflagellates observed resulted in relatively low grazing impacts $(<10 \%$ of bacterial standing stock). We found a significant negative correlation between $\mathrm{PO}_{4}$ concentrations and ingestion rates of the 3-6 $\mu \mathrm{m}$ PNF, suggesting that the PNF ingestion rate increased under nutrient-deficient conditions.
\end{abstract}

KEY WORDS: Pigmented nanoflagellates $\cdot$ Mixotrophy $\cdot$ Subtropical western Pacific $\cdot$ Fluorescently labeled bacteria $\cdot$ Ingestion rates

\section{INTRODUCTION}

Bacteria are generally considered to be consumed mainly by heterotrophic nanoflagellates (HNF) and ciliates in both marine and freshwater environments (Berninger et al. 1991, Epstein \& Shiaris 1992, Hall et al. 1993, Nakano et al. 1998, Almeida et al. 2001, Christaki et al. 2001, Cleven \& Weisse 2001, Ichinotsuka et al. 2006). However, increasing evidence from natural environments suggests that pigmented nanoflagellates
(PNF) can also contribute greatly to bacterivory at certain times or at certain depths within the water column (Bird \& Kalff 1986, Sanders et al. 1989, Berninger et al. 1992, Hall et al. 1993, Havskum \& Riemann 1996, Safi \& Hall 1999, Hitchman \& Jones 2000, Medina-Sánchez et al. 2004, Unrein et al. 2007). For example, Havskum \& Riemann (1996) reported that the PNF were responsible for $86 \%$ of the entire nanoflagellate bacterivory in the upper layer of the Bay of Aarhus, but accounted for only $19 \%$ below the pycnocline. Therefore, PNF 
can significantly affect the flow of organic matter in the microbial food web of some aquatic environments.

Water temperature and the abundance of prey are usually considered among the most important factors regulating the phagotrophic activity of HNF (Choi 1994, Vaqué et al. 1994). However, a range of environmental factors, including light, prey abundance and nutrients, can affect the feeding behavior of PNF and it is unlikely that there is a single explanation or a universal stimulus for the ingestion of particles by PNF (Bird \& Kalff 1986, Salonen \& Jokinen 1988, Caron et al. 1993, Nygaard \& Tobiesen 1993, Holen 1999, Moorthi \& Berninger 2006, Unrein et al. 2007). In some studies, PNF feeding rates have been found to increase in low-light conditions or in darkness (Hall et al. 1993, Holen 1999), but to decrease under limited light conditions in other studies (Caron et al. 1993, Jones \& Rees 1994). One analysis found that light had no effect at all on the feeding rates of PNF (Sanders et al. 2001). Previous studies have reported that PNF are very important bacterial grazers in nutrient-insufficient conditions (Nygaard \& Tobiesen 1993, Arenovski et al. 1995, Havskum \& Riemann 1996). Unrein et al. (2007) suggested that PNF could rely on their phagotrophic capabilities to obtain phosphorus when this nutrient is limited. Conversely, Bird \& Kalff (1986) showed that PNF were able to assimilate organic carbon and other nutrients, such as phosphorus, from the ingestion of prey. It also has been suggested that bacterivory by PNF could be a means of removing competitors for nutrients (Thingstad et al. 1996) and simultaneously obtaining phosphorus (Urabe et al. 1999). These suggestions are based on the fact that bacteria compete better for inorganic $\mathrm{P}$ than do most phytoplankton because they have a higher surface-to-volume ratio (Currie \& Kalff 1984, Probyn et al. 1990) and they have a higher internal P:N ratio compared with phytoplankton (Jürgens \& Güde 1990).

In prior investigations using fluorescent particles as Synechococcus spp. equivalents at our study site, evidence suggested that PNF were the main grazers of Synechococcus spp., and that HNF had little grazing impact on cyanobacteria in subtropical western Pacific coastal waters (Tsai et al. 2007, Chan et al. 2009). These authors hypothesized that while HNF are usually the main consumers of bacteria, the grazing impacts of HNF and PNF on bacteria are significantly different in subtropical western Pacific coastal waters.

The present study investigates the impact of different sizes of PNF and HNF (2-3, 3-6 and 6-10 $\mu \mathrm{m})$ on bacteria during the warm season (May to September) in a coastal ecosystem of the subtropical western Pacific, and it examines factors that potentially regulate the grazing behavior of HNF and PNF.

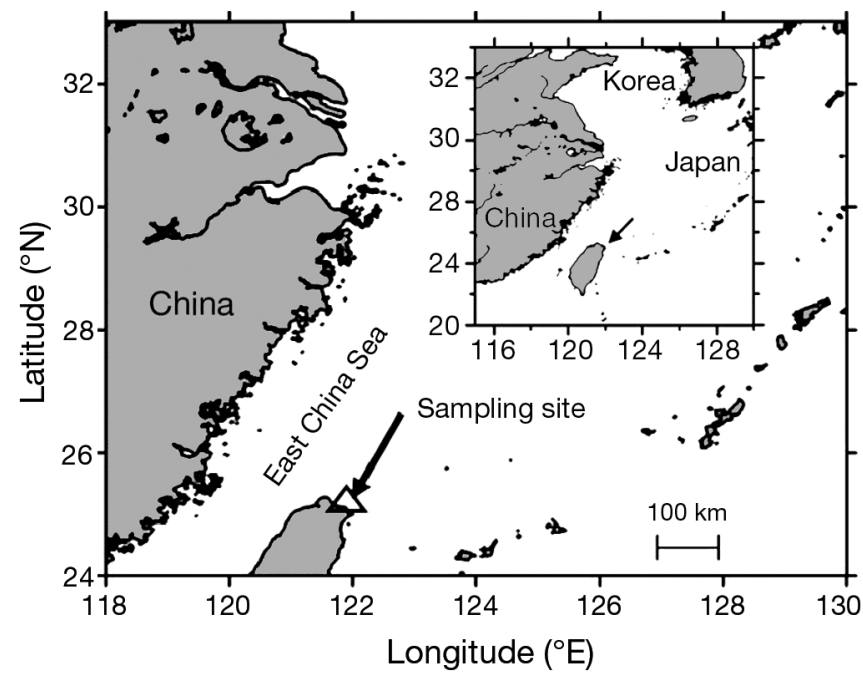

Fig. 1. The sampling station, northeastern Taiwan

\section{MATERIALS AND METHODS}

Sampling. Samples were collected weekly from May to September 2009 at an established coastal station $\left(25^{\circ} 09.4^{\prime} \mathrm{N}, 121^{\circ} 46.3^{\prime} \mathrm{E}\right)$ along a rocky shore in northeastern Taiwan (Fig. 1). The environment at this site was previously described on the basis of data gathered from 1999 to 2001 (Tsai et al. 2005). Water temperature is constantly above $25^{\circ} \mathrm{C}$ between June and October, and daytime temperatures are generally 0.5 to $1.5^{\circ} \mathrm{C}$ higher than nighttime temperatures (Tsai et al. 2005). Annually, salinity ranges from 33.1 to 34.3 , the lower salinity within this range likely reflecting the influence of rainfall runoff.

During this study in the warm season of 2009, surface seawater was collected between 09:00 and 10:00 h local time. Water temperature was measured immediately, and all samples were brought to the laboratory within $30 \mathrm{~min}$. Nitrate, phosphate and silicate were measured according to Gong et al. (1995). Water samples were filtered ( $25 \mathrm{~mm} \mathrm{GF/F)} \mathrm{and,} \mathrm{after} \mathrm{extraction,}$ chlorophyll a (chl a) was measured with an in vitro fluorometer (Turner Design 10-AU-005) (Parsons et al. 1984).

Bacteria, HNF and PNF. For enumeration, $50 \mathrm{ml}$ water samples were fixed with glutaraldehyde to a final concentration of $1 \%$ (Christaki et al. 1999, Sanders et al. 2000), and 1 to $2 \mathrm{ml}$ or $20 \mathrm{ml}$ were filtered onto black Nuclepore filters of pore size $0.2 \mu \mathrm{m}$ or $0.8 \mu \mathrm{m}$ for bacteria and nanoflagellates, respectively. Samples were stained with DAPI (4',6-diamidino-2phenylindole) at a final concentration of $1 \mu \mathrm{g} \mathrm{ml} \mathrm{m}^{-1}$ (Porter \& Feig 1980). PNF and HNF were enumerated according to the presence or absence of chlorophyll autofluorescence using a separate filter set optimized 


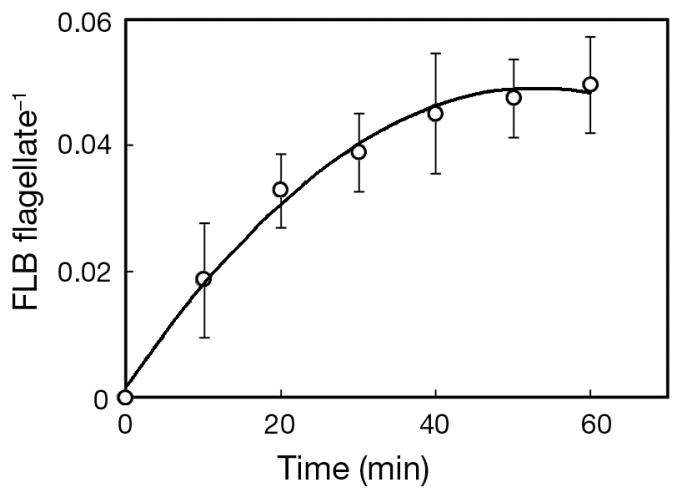

Fig. 2. Time course of uptake of fluorescently labeled bacteria (FLB) by flagellates from the study site

for chlorophyll or DAPI under a 1000× epifluorescence microscope (Nikon-Optiphot-2). Bacteria and HNF were identified by their blue fluorescence under ultraviolet (UV) illumination, and PNF were identified by their orange and red autofluorescence under bluelight excitation. To obtain reliable estimates of abundance we counted 30 and 50 fields of view for bacteria and nanoflagellates, respectively.

Grazing experiments. Grazing rates of HNF and PNF feeding on bacteria were determined using fluorescently labeled bacteria (FLB) generally following the methods of Sherr et al. (1987). FLB were prepared from natural bacterioplankton collected from our study site, stored frozen in $10 \mathrm{ml}$ aliquots, thawed, and briefly sonicated prior to use. FLB were distinguished from the natural bacteria by the bright green color of the FLB under blue-light excitation using an epifluorescence microscope.

In grazing experiments, which were done in triplicate, surface water was filtered though a $20 \mu \mathrm{m}$ nylon mesh into $500 \mathrm{ml}$ polycarbonate bottles and then FLB were added to the bottles at $<10 \%$ of the in situ bacterial abundance (McManus \& Okubo 1991). Bottles were incubated in a water bath at in situ temperature and light intensities for $1 \mathrm{~h}$. Preliminary experiments indicated that ingestion of FLB by nanoflagellates was saturated after 40 to 60 min (Fig. 2). After the incubation, $20 \mathrm{ml}$ subsamples were preserved with glutaraldehyde (to $1 \% \mathrm{v} / \mathrm{v}$ final conc.), and the number of FLB ingested by nanoflagellates was determined using epifluorescence microscopy (magnification $1000 \times$ ). In order to understand the role played in feeding by HNF and PNF of different sizes, we divided HNF and PNF into 3 size categories: 2-3, 3-6, and $6-10 \mu \mathrm{m}$, and recorded their FLB content separately. Ingestion rates of FLB (FLB $\mathrm{HNF}^{-1} \mathrm{~h}^{-1}$; FLB $\mathrm{PNF}^{-1} \mathrm{~h}^{-1}$ ) were calculated according to Dolan \& Šimek (1998). Ingestion rates (bacteria $\mathrm{HNF}^{-1} \mathrm{~h}^{-1}$; bacteria $\mathrm{PNF}^{-1} \mathrm{~h}^{-1}$ ) were then calculated by multiplying the ingestion rate of FLB by the ratio of bacteria to added FLB (Pace et al. 1990). Community consumption rates (bacteria $\mathrm{ml}^{-1} \mathrm{~h}^{-1}$ ) were estimated by multiplying average ingestion rates on bacteria and total HNF and PNF abundance.

To assess the differences in PNF and HNF ingestion and consumption rates, $t$-tests were undertaken, while

Table 1. Temperature, salinity, chlorophyll a (chl a) and nutrient $\left(\mathrm{NO}_{3}, \mathrm{NO}_{2}\right.$ and $\left.\mathrm{PO}_{4}\right)$ concentrations in the coastal ecosystem of subtropical western Pacific during the summer period in 2009. nd = no data

\begin{tabular}{|c|c|c|c|c|c|c|}
\hline Date & Temperature $\left({ }^{\circ} \mathrm{C}\right)$ & Salinity & Chl a $\left(\mathrm{mg} \mathrm{m}^{-3}\right)$ & $\mathrm{NO}_{3}\left(\mu \mathrm{mol} \mathrm{l}{ }^{-1}\right)$ & $\mathrm{NO}_{2}\left(\mu \mathrm{mol} \mathrm{l} \mathrm{l}^{-1}\right)$ & $\mathrm{PO}_{4}\left(\mu \mathrm{mol} \mathrm{l}{ }^{-1}\right)$ \\
\hline May 8 & 23.0 & nd & nd & nd & nd & nd \\
\hline May 15 & 23.0 & 34.01 & 0.35 & 1.26 & 0.18 & 0.19 \\
\hline May 23 & 26.0 & 34.06 & 0.51 & 0.61 & 0.17 & 0.10 \\
\hline May 29 & 27.0 & 33.99 & 0.38 & 0.44 & 0.10 & 0.11 \\
\hline Jun 5 & 27.0 & 33.89 & 0.48 & 3.16 & 0.19 & 0.17 \\
\hline Jun 12 & 27.0 & 33.82 & 0.46 & 0.44 & 0.08 & 0.06 \\
\hline Jun 19 & 28.0 & 33.71 & 0.37 & 0.56 & 0.11 & 0.09 \\
\hline Jun 26 & 29.0 & 33.90 & 0.56 & 0.43 & 0.13 & 0.14 \\
\hline Jul 10 & 29.0 & 33.48 & 0.39 & 0.15 & 0.05 & 0.06 \\
\hline Jul 17 & 29.5 & 33.31 & 0.65 & 0.19 & 0.12 & 0.12 \\
\hline Jul 21 & 28.0 & 33.41 & 0.63 & 0.41 & 0.17 & 0.22 \\
\hline Jul 23 & 28.5 & nd & nd & nd & nd & nd \\
\hline Jul 30 & 28.0 & 33.12 & 0.57 & 3.09 & 0.47 & 0.42 \\
\hline Aug 8 & 28.0 & 33.54 & 0.78 & 1.80 & 0.19 & 0.23 \\
\hline Aug 13 & 28.0 & 33.10 & 1.06 & 1.70 & 0.15 & 0.06 \\
\hline Aug 20 & 28.0 & 33.10 & 0.58 & 1.40 & 0.20 & 0.11 \\
\hline Aug 27 & 28.0 & 33.29 & 0.96 & 6.60 & 0.11 & 0.30 \\
\hline Sep 3 & 27.0 & 33.32 & 0.15 & 2.00 & 0.34 & 0.35 \\
\hline Sep 10 & 28.5 & 33.55 & 0.28 & nd & 0.13 & 0.32 \\
\hline Sep 17 & 27.0 & 32.66 & 0.42 & nd & 0.84 & nd \\
\hline Sep 24 & 25.0 & nd & nd & nd & nd & nd \\
\hline
\end{tabular}


1-way analysis of variance (ANOVA) and Tukey tests were applied to assess significant differences in ingestion and consumption rates for different sizes of PNF and HNF. All statistical analyses were performed using SPSS version 11.0.

\section{RESULTS}

\section{Physical and chemical environment}

Surface water temperature at our site fluctuated between $23.0^{\circ} \mathrm{C}$ (May 8) and $29.5^{\circ} \mathrm{C}$ (July 17) throughout the study period (Table 1 ). Salinity ranged from 32.66 to 34.06 , with the lowest salinity reflecting the influence of heavy rainfall runoff before sampling (Table 1). Typically, concentrations of nutrients were low during the warm season (May to September), with $\mathrm{NO}_{3}, \mathrm{NO}_{2}$ and $\mathrm{PO}_{4}$ varying from 0.15 to $6.60 \mu \mathrm{mol} \mathrm{l} \mathrm{l}^{-1}$, 0.08 to $0.84 \mu \mathrm{mol} \mathrm{l}^{-1}$ and 0.06 to $0.42 \mu \mathrm{mol} \mathrm{l^{-1 }}$, respectively (Table 1).

\section{Abundance of bacteria and nanoflagellates}

Concentrations of chl a ranged from 0.15 to $1.06 \mathrm{mg}$ $\mathrm{m}^{-3}$, and bacterial abundance followed a pattern similar to that of chl a (Fig. 3A). Pearson correlation analysis showed a positive and significant correlation be-

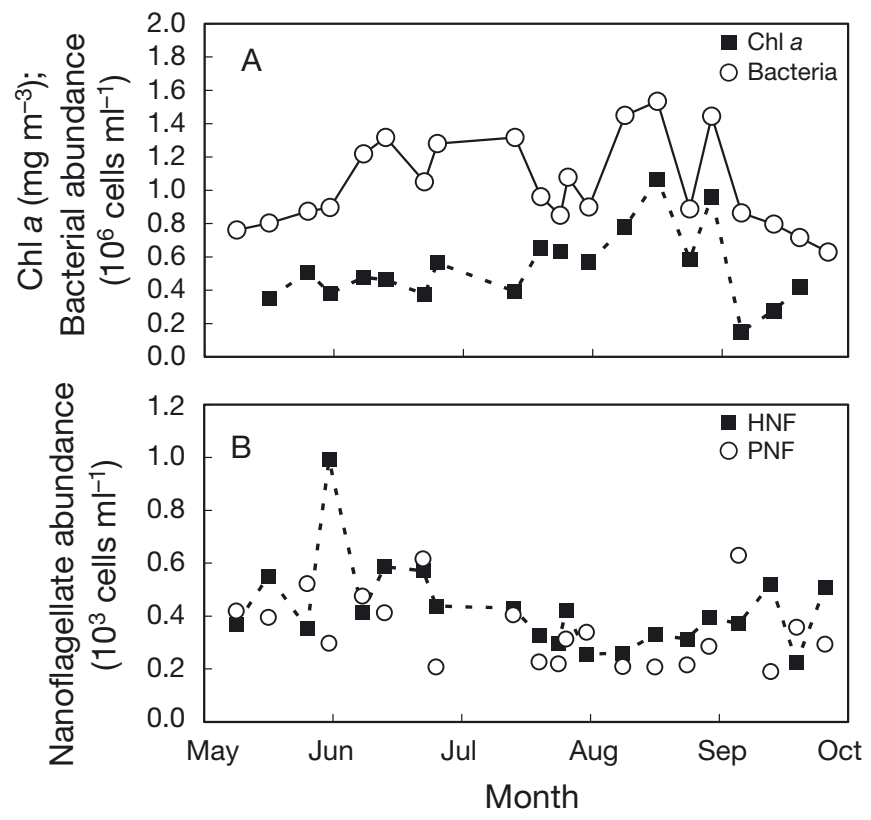

Fig. 3. (A) Temporal variations in concentrations of chlorophyll a $(\mathrm{Chl} \mathrm{a})$ and bacterial abundance, and (B) the abundance of heterotrophic nanoflagellates (HNF) and pigmented nanoflagellates (PNF) from May to September 2009

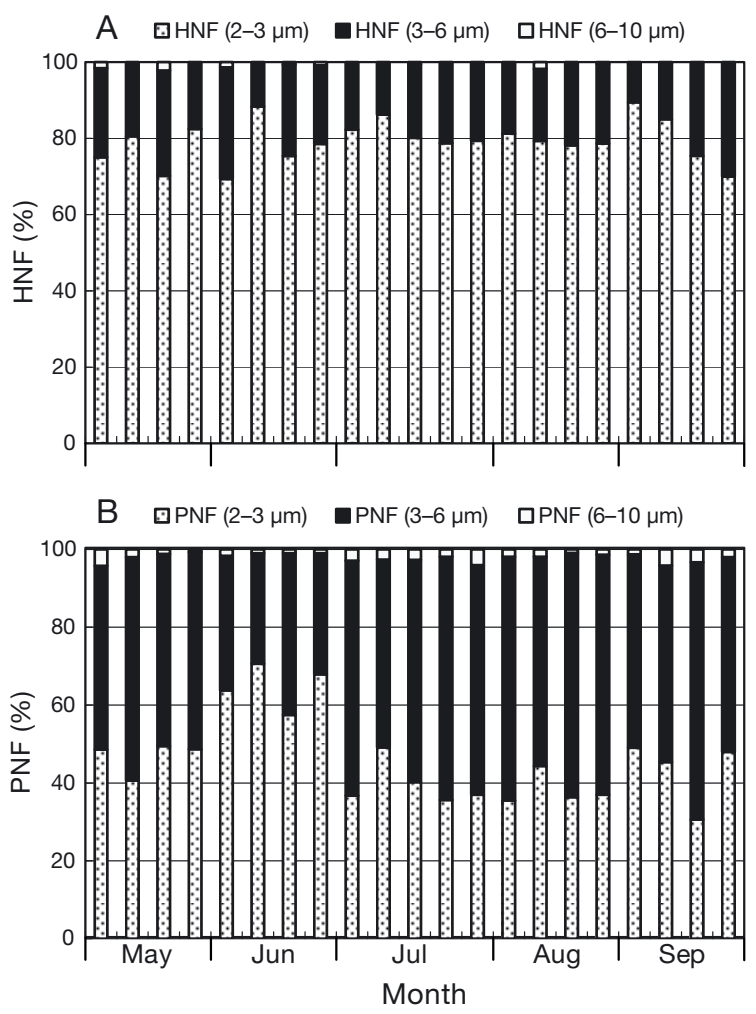

Fig. 4. Percentage contributions of 3 size classes $(2-3,3-6$ and $6-10 \mu \mathrm{m})$ to the total abundance of (A) heterotrophic nanoflagellates (HNF) and (B) pigmented nanoflagellates (PNF)

tween chl a concentration and bacterial abundance $(\mathrm{r}=$ $0.65, \mathrm{p}<0.05$ ) (data not shown).

Nanoflagellate abundance showed no consistent trend during the study period (Fig. 3B). The abundance of HNF and PNF generally ranged from 200 to 600 cells $\mathrm{ml}^{-1}$, though the highest abundance of HNF observed at the end of May was 990 cells ml $^{-1}$ (Fig. 3B). No significant difference was detected between HNF and PNF abundance over the entire investigation period ( $t$-test, $\mathrm{p}>0.05)$.

HNF and PNF $>6 \mu \mathrm{m}$ in size were always a minor component of the total nanoflagellate community. HNF in the 2-3 $\mu \mathrm{m}$ size class dominated the HNF community, ranging from 69 to $89 \%$ of total HNF abundance (average $79 \%$ ) (Fig. 4A). Abundance of the 2-3 $\mu \mathrm{m}$ PNF accounted for 31 to $71 \%$ (average $46 \%$ ) of total PNF, while 28 to $66 \%$ of the PNF were between 3 and $6 \mu \mathrm{m}$ (average 52\%) (Fig. 4B).

\section{Grazing on bacteria by the HNF and PNF assemblages}

The grazing rates of HNF and PNF, estimated on the basis of direct uptake of FLB, ranged from 0.2 to 2.0 

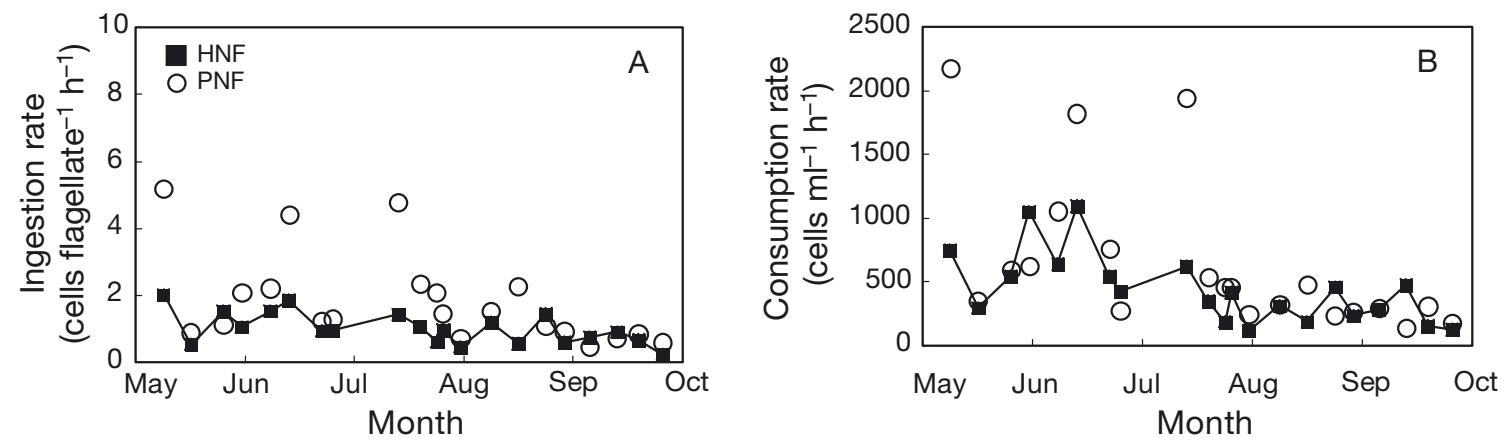

Fig. 5. Temporal variations in (A) ingestion and (B) community consumption rates of heterotrophic nanoflagellates (HNF) and pigmented nanoflagellates (PNF)

cells $\mathrm{HNF}^{-1} \mathrm{~h}^{-1}$ and from 0.5 to 5.2 cells $\mathrm{PNF}^{-1} \mathrm{~h}^{-1}$, respectively (Fig. 5A). The highest grazing rates for PNF ( $>4$ cells PNF $^{-1} h^{-1}$ ) were observed between May and July, although more moderate rates were also found during these months (Fig. 5A). During most grazing experiments, the range of ingestion rates of HNF and PNF on bacteria were narrower $\left(0.2\right.$ to 2.3 cells flagellate ${ }^{-1} \mathrm{~h}^{-1}$, Fig. 5A).

The grazing impact (community consumption) on bacteria was generally greater in May through July, especially when PNF had high ingestion rates (Fig. 5). The effect of PNF grazing ( $>1500$ cells $\mathrm{ml}^{-1} \mathrm{~h}^{-1}$ ) was 3 times greater than that of HNF on 3 dates from May to July (Fig. 5B). Otherwise, hourly consumption of bacteria by both HNF and PNF was lower, varying from 120 to 1100 cells ml ${ }^{-1} \mathrm{~h}^{-1}$, respectively, and there was no significant difference in consumption rates between HNF and PNF ( $t$-test, $\mathrm{p}>0.05)$ across the complete data set (Fig. 5B).

\section{Grazing by different size classes of nanoflagellates}

Nanoflagellate size appeared to affect cell-specific ingestion rates of bacteria. Among the bacterivorous HNF community, HNF of 2-3 $\mu \mathrm{m}$ were considerably less efficient feeders with lower maximum ingestion rates $(<1.5$ bacteria $\mathrm{HNF}^{-1} \mathrm{~h}^{-1}$ ) than the larger HNF (Fig. 6A). On the other hand, the higher grazing rates of 6-10 $\mu \mathrm{m}$ HNF did not translate into large feeding impacts on the bacteria because of their generally low abundance ( 0 to 10 cells $\mathrm{ml}^{-1}$, data not shown). Overall, the 3-6 $\mu \mathrm{m}$ HNF had higher ingestion rates $\left(0.3\right.$ to 5.8 bacteria $\left.\mathrm{HNF}^{-1} \mathrm{~h}^{-1}\right)$ than did the other size classes of HNF (ANOVA, Tukey, p < 0.05) (Fig. 6A). The ingestion rates of the $2-3 \mu \mathrm{m}$ PNF on bacteria were very low $\left(0-0.7\right.$ cells $\left.\mathrm{PNF}^{-1} \mathrm{~h}^{-1}\right)$ during the whole study

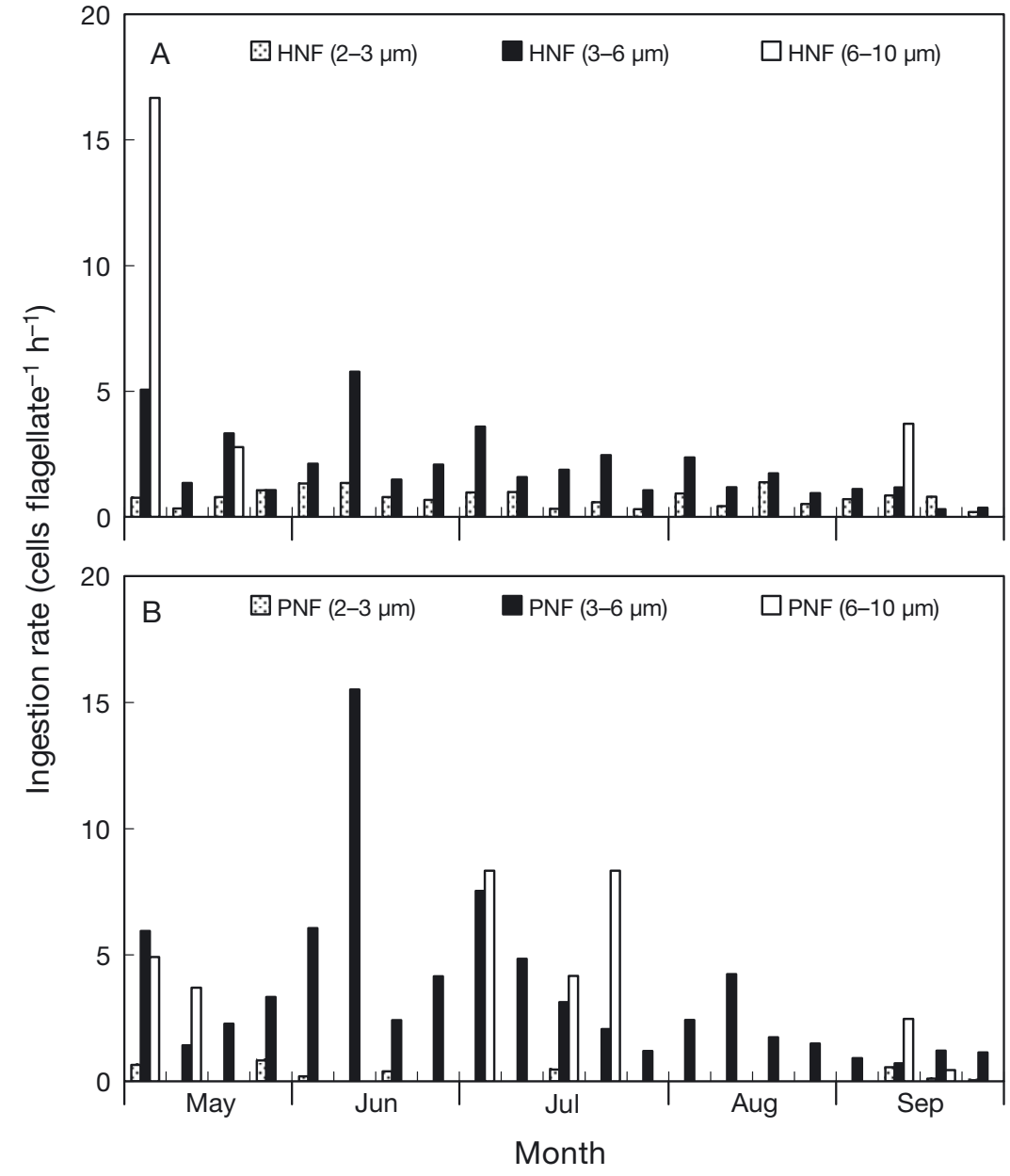

Fig. 6. Temporal variations in ingestion rates of 3 size classes $(2-3,3-6$ and 6-10 $\mu \mathrm{m}$ ) of (A) heterotrophic nanoflagellates (HNF) and (B) pigmented nanoflagellates (PNF) 


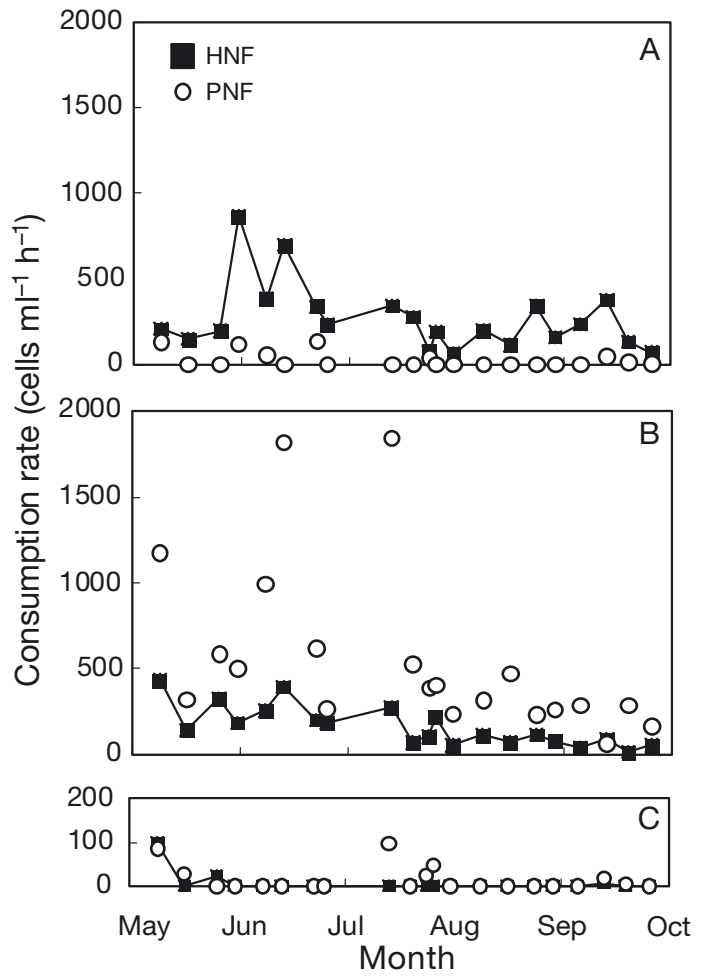

Fig. 7. Temporal variations in community consumption rates of (A) 2-3 $\mu \mathrm{m}$, (B) 3-6 $\mu \mathrm{m}$, and (C) 6-10 $\mu \mathrm{m}$ heterotrophic nanoflagellates (HNF) and pigmented nanoflagellates (PNF)

period, while the ingestion rates of 3-6 $\mu \mathrm{m}$ PNF fluctuated from 0.9 to 15.5 cells $\mathrm{PNF}^{-1} \mathrm{~h}^{-1}$ (Fig. 6B), with the highest value recorded in June.

In terms of grazing impact on bacteria, the $2-3 \mu \mathrm{m}$ HNF and 3-6 $\mu \mathrm{m}$ HNF were the major consumers of bacteria in the HNF community ( 60 to 860 cells ml ${ }^{-1} \mathrm{~h}^{-1}$ and 20 to 440 cells $\mathrm{ml}^{-1} \mathrm{~h}^{-1}$, respectively) (Fig. $7 \mathrm{~A}, \mathrm{~B}$ ). The grazing impact of 3-6 $\mu \mathrm{m}$ PNF was greater than the other size categories of PNF (ANOVA, Tukey, $\mathrm{p}<$ 0.05 ) and often greater than that of the HNF community (Fig. 7B). The grazing impact of both HNF and PNF in the $6-10 \mu \mathrm{m}$ size range was negligible ( 0 to $98 \mathrm{cells} \mathrm{ml}^{-1}$ $\mathrm{h}^{-1}$, Fig. $7 \mathrm{C}$ ) because of the low abundance of flagellates in this size category (Fig. 4). Regardless of the presence of a chloroplast, nanoflagellates $<6 \mu \mathrm{m}$ accounted for about $98 \%$ of the total bacterivory (Fig. 8). PNF of 3-6 $\mu \mathrm{m}$ in size were responsible for 12 to $72 \%$ of the bacterivory (average $52 \%$ ) , 2-3 $\mu \mathrm{m} \mathrm{HNF}$ for 9.8 to $61.9 \%$ and $3-6 \mu \mathrm{m}$ HNF for 3.6 to $28.7 \%$ (Fig. 8).

\section{DISCUSSION}

It is now commonly accepted that nanoflagellates are the most important grazers of bacteria in most aquatic environments (Epstein \& Shiaris 1992, Nakano et al. 1998, Safi \& Hall 1999, Sanders et al. 2000, Tsai et al. 2005, 2008, Ichinotsuka et al. 2006), though some planktonic ciliates also can be significant consumers of bacteria (Rassoulzadegan et al. 1988, Jürgens \& Šimek 2000, Kisand \& Zingel 2000). On an individual basis, a bacterivorous ciliate may graze an order of magnitude more bacterial cells than a nanoflagellate (Šimek \& Straškrabová 1992, James et al. 1996, Ichinotsuka et al. 2006). However, ciliate abundance is usually less than that of nanoflagellates in marine environments, so total grazing pressure on bacteria by ciliates is usually lower than that of nanoflagellates. In the present study, the low abundance of ciliates $\left(\sim 1 \mathrm{cell} \mathrm{ml}^{-1}\right)$ (A.-Y. Tsai unpubl. data), resulted in negligible consumption of

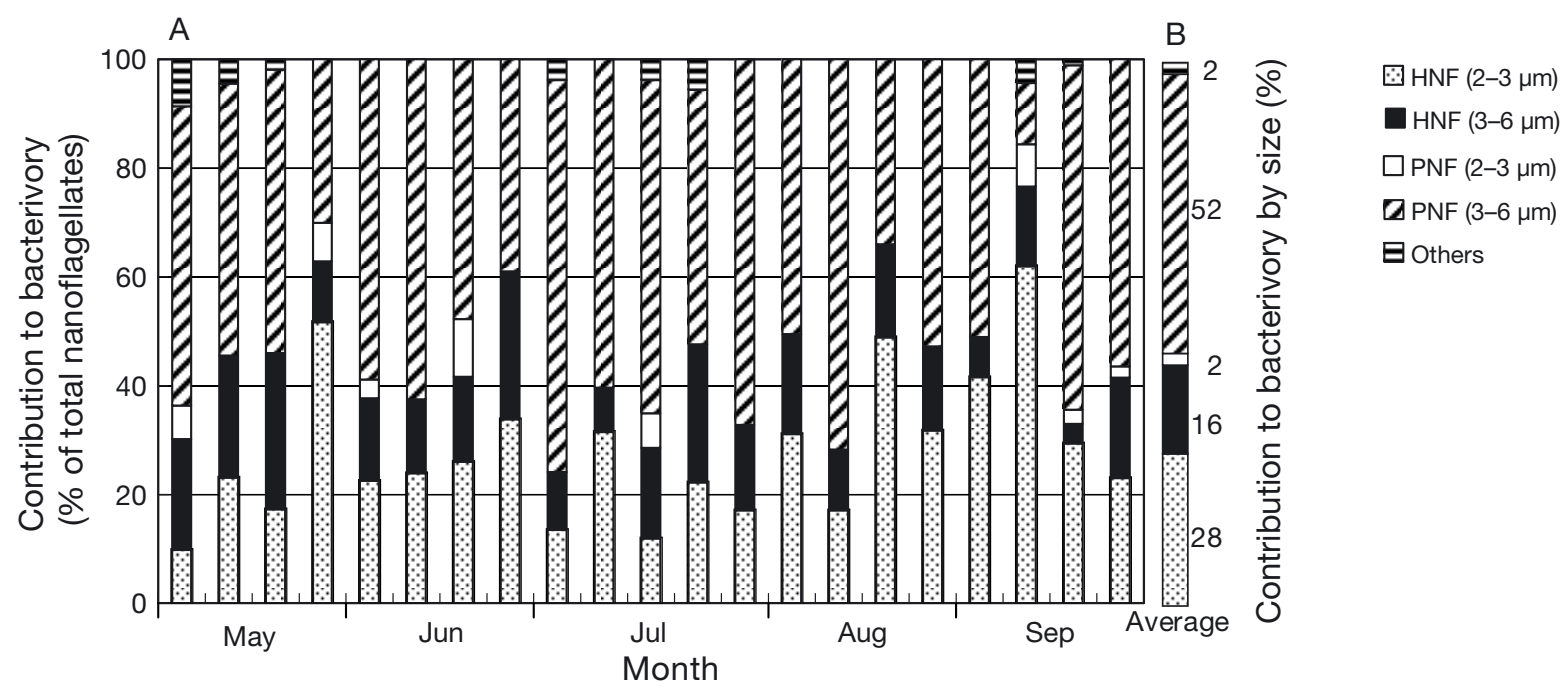

Fig. 8. Proportion of bacterivory (in \%) contributed by each size class of heterotrophic nanoflagellates (HNF) and pigmented nanoflagellates (PNF) (A) throughout the study period and (B) as average values 
bacteria by ciliates relative to that by HNF or PNF. Furthermore, in a previous study in the same general area, ciliates removed only $\sim 3 \%$ of the Synechococcus spp. production, despite high ingestion rates by individual ciliates (Tsai et al. 2007). In that study, the grazing impact by PNF was 20 times that of ciliates, and PNF were clearly the key warm-season grazers of Synechococcus spp. (Tsai et al. 2007). Taken together, these results confirm a report by Tsai et al. (2005) that nanoflagellates were the most important grazers of picoplankton (bacteria and Synechococcus spp.) at our study site.

Some previous studies showed that the smallest HNF were primarily bacterivorous (Sherr \& Sherr 2002, Unrein et al. 2007). In our study, HNF 2-3 $\mu \mathrm{m}$ in size grazed fewer bacterial cells on an individual basis than did larger HNF (e.g. 3-6 $\mu \mathrm{m}$ HNF) (Fig. 6A). However, the abundance of 2-3 $\mu \mathrm{m}$ HNF was usually greater than that of other HNF, and grazing pressure on bacteria by $2-3 \mu \mathrm{m}$ HNF was thus higher than that by other HNF. In the present study, $28 \%$ of the total measured bacterivory was attributed to HNF 2-3 $\mu \mathrm{m}$ in size (Fig. 8B), a significantly higher grazing effect than the larger HNF (3-6 $\mu \mathrm{m}$ or $6-10 \mu \mathrm{m}$ HNF). The grazing impact of $>6 \mu \mathrm{m}$ HNF and PNF on bacteria was considerably lower than for other nanoflagellates $(2 \%$ grazing effect, Fig. 8B). This suggests that they obtain most of their carbon by feeding on larger prey (or by photosynthesis). Havskum \& Riemann (1996) reported that larger nanoflagellates typically fed on prey larger than bacteria, and as noted above for PNF, HNF can also feed on phototrophic picoplankton (Sherr et al. 1991). In agreement with this view of larger flagellates ingesting larger prey, Vaqué et al. (2008) found that there were 2 trophic chains: one from bacteria to $<5 \mu \mathrm{m}$ HNF and another beginning with prey larger than bacteria, such as small algae, and leading to $>5 \mu \mathrm{m}$ HNF. Grazing by larger nanoflagellates on the smaller size fractions of nanoflagellates could complicate the interpretation of microbial food webs. Lin et al. (2009) observed an indirect trophic cascade grazing pattern at our study site, in which nanoflagellates 2-5 $\mu \mathrm{m}$ in size were the principal predators of picoplankton, and these small nanoflagellates were, in turn, consumed by 5-20 $\mu \mathrm{m}$ nanoflagellates. Feeding on small flagellates by larger ones may partly explain their consequently relatively low impact on the bacterial standing stock (Table 2).

A maximum of $\sim 9 \%$ of bacterial standing stock $(\sim 7 \times$ $10^{4}$ cells $\mathrm{ml}^{-1} \mathrm{~d}^{-1}$ ) was calculated to be consumed by nanoflagellates in the present study (Table 2). Running the feeding experiments for $1 \mathrm{~h}$ may have underestimated the ingestion rates, if the number of FLB ingested had begun to plateau earlier in the experiments as in Fig. 2; the rate determined at $1 \mathrm{~h}$ was only $58 \%$ of the rate determined from a linear fit to the first $30 \mathrm{~min}$ of the time course. This suggests that ingestion rates and impact could be nearly double what we report. It is also possible that grazing rates in the present study could be underestimated due to feeding selectivity

Table 2. Bacterial abundance and consumption of bacteria by heterotrophic (HNF) and pigmented (PNF) nanoflagellates

\begin{tabular}{|c|c|c|c|c|c|}
\hline \multirow{2}{*}{$\begin{array}{l}\text { Date } \\
(2009)\end{array}$} & \multirow{2}{*}{$\begin{array}{l}\text { Bacterial abundance } \\
\quad\left(10^{6} \text { cells } \mathrm{ml}^{-1}\right)\end{array}$} & \multicolumn{2}{|c|}{ Consumption rates $\left(10^{4}\right.$ cells ml $\left.{ }^{-1} \mathrm{~d}^{-1}\right)$} & \multicolumn{2}{|c|}{ Bacterial standing stock ingested (\%) } \\
\hline & & HNF & PNF & HNF & PNF \\
\hline May 8 & 0.76 & 1.78 & 5.22 & 2.34 & 6.86 \\
\hline May 15 & 0.80 & 0.71 & 0.85 & 0.88 & 1.05 \\
\hline May 23 & 0.87 & 1.30 & 1.41 & 1.49 & 1.62 \\
\hline May 29 & 0.90 & 2.52 & 1.49 & 2.81 & 1.66 \\
\hline Jun 5 & 1.22 & 1.53 & 2.53 & 1.25 & 2.08 \\
\hline Jun 12 & 1.32 & 2.62 & 4.37 & 1.99 & 3.32 \\
\hline Jun 19 & 1.05 & 1.30 & 1.82 & 1.23 & 1.73 \\
\hline Jun 26 & 1.28 & 1.01 & 0.64 & 0.79 & 0.50 \\
\hline Jul 10 & 1.32 & 1.48 & 4.66 & 1.13 & 3.54 \\
\hline Jul 17 & 0.96 & 0.84 & 1.27 & 0.87 & 1.33 \\
\hline Jul 21 & 0.85 & 0.44 & 1.10 & 0.51 & 1.29 \\
\hline Jul 23 & 1.08 & 0.99 & 1.09 & 0.92 & 1.01 \\
\hline Jul 30 & 0.90 & 0.28 & 0.57 & 0.31 & 0.64 \\
\hline Aug 8 & 1.45 & 0.75 & 0.76 & 0.52 & 0.53 \\
\hline Aug 13 & 1.53 & 0.45 & 1.14 & 0.29 & 0.74 \\
\hline Aug 20 & 0.89 & 1.09 & 0.56 & 1.23 & 0.64 \\
\hline Aug 27 & 1.44 & 0.56 & 0.63 & 0.39 & 0.44 \\
\hline Sep 3 & 0.86 & 0.66 & 0.69 & 0.77 & 0.80 \\
\hline Sep 10 & 0.80 & 1.13 & 0.32 & 1.43 & 0.41 \\
\hline Sep 17 & 0.72 & 0.36 & 0.73 & 0.50 & 1.02 \\
\hline Sep 24 & 0.63 & 0.29 & 0.42 & 0.47 & 0.66 \\
\hline
\end{tabular}


(Landry et al. 1991). Nonetheless, ingestion rates reported here are within the range determined in other environments with greater grazing impact by nanoflagellates (Christaki et al. 2001, Cleven \& Weisse 2001, Jezbera et al. 2003). Thus, the low grazing in the present study seems to be mostly a consequence of the low abundances of nanoflagellates present on most of the sampling dates. Flagellates, as expected, seem to be the major protistan bacterivores in this coastal system. Their low overall impact on bacteria $(\sim 20 \%$ of the bacterial production expected in the area based on other cruises, A.-Y. Tsai unpubl. data), indicates that alternative sources of bacterial mortality, such as lysis by viruses and bacterivory by other organisms (Sanders et al. 1989, Vaque \& Pace 1992, Fuhrman \& Noble 1995, Hwang \& Heath 1999, Almeida et al. 2001, Taira et al. 2009) may also be important in this environment.

Grazing on bacteria by HNF has been estimated using the FLB method in numerous ocean and coastal sea environments (James et al. 1996, González et al. 1998, Safi \& Hall 1999, Sime-Ngando et al. 1999, Ichinotsuka et al. 2006). However, only a few studies have made comparisons between bacterivory rates by HNF and PNF, and information on the importance of these groups of grazers in oceans and coastal seas is still limited (Epstein \& Shiaris 1992, Hall et al. 1993, Safi \& Hall 1999, Sanders et al. 2000, Unrein et al. 2007, Moorthi et al 2009). The present study found no significant difference between the abundance of PNF and HNF in the coastal waters off Taiwan. Furthermore, PNF and HNF were responsible for approximately equal consumption of bacteria (56 and $44 \%$ of the total ingestion, respectively).

The smallest size category of PNF $(2-3 \mu \mathrm{m})$ was relatively very abundant during the summer period (averaged $46 \%$ of total PNF, Fig. 4B), but never ingested bacteria at a significant rate; HNF 2-3 $\mu \mathrm{m}$ in size had a significantly higher grazing effect than did the $2-3 \mu \mathrm{m}$ PNF (Fig. 7). These results suggest that most of the 2-3 $\mu \mathrm{m}$ PNF were primarily autotrophic. This finding is consistent with a previous study (Unrein et al. 2007) that observed no ingestion of bacteria by PNF $<3 \mu \mathrm{m}$ in size, but differs from another (Zubkov \& Tarran 2008) in which the smallest PNF were strongly bacterivorous. During the summer period of our study, the consumption rates of PNF 3-6 $\mu \mathrm{m}$ in size were considerably higher than those of HNF of the same size (Fig. 7B), and they made up the majority of the bacterivorous PNF community (Fig. 4B).

In several studies, the impact of PNF grazing was important and accounted for up to $86 \%$ of the total bacterivory (Berninger et al. 1992, Arenovski et al. 1995, Havskum \& Riemann 1996, Sanders et al. 1989, 2000). Reviews of PNF bacterivory in both freshwater and marine environments report highly variable clear- ance rates among different PNF populations (Jones 1994, Safi \& Hall 1999, Sanders et al. 2000, Unrein et al. 2007), but still suggest that PNF can be important grazers on bacteria and picophytoplankton, especially in oligotrophic waters. To date, there are not enough data to support a clear explanation for PNF ingestion of bacteria at a given site. A range of environmental factors (nutrients, light, prey abundance) may all affect the abundance and feeding behavior of PNF (Bird \& Kalff 1986, Salonen \& Jokinen 1988, Caron et al. 1993, Nygaard \& Tobiesen 1993, Holen 1999, Sanders et al. 2000, Moorthi \& Berninger 2006, Unrein et al. 2007). In most cases, photosynthesis would presumably be the primary energy source for these PNF, while phagotrophy would allow them to compete successfully with non-phagotrophic algae for growth-limiting nutrients. Such a strategy for growth might be particularly useful in oligotrophic waters (Arenovski et al. 1995).

In the present study, we did not evaluate the importance of light availability influencing the feeding behavior of PNF, as all the experiments were performed under lighted conditions. Furthermore, we did not find any relationship between the ingestion rates of PNF and bacterial abundance. However, there was a significantly negative correlation between $\mathrm{PO}_{4}$ concentrations and ingestion rates by the 3-6 $\mu \mathrm{m}$ PNF (Fig. 9). This indicates a tendency toward increased ingestion at low $\mathrm{PO}_{4}$ concentrations, which is consistent with nutrient uptake via phagotrophy permitting mixotrophic phytoplankton to outcompete other phytoplankton when dissolved nutrients are restricted. Support for this explanation is found in a study by Nygaard \& Tobiesen (1993) who found that marine mixotrophic nanoflagellates have higher ingestion rates in P-limited conditions. Another nutrient enrichment experiment with Sargasso Sea populations also produced marked declines in phagotrophically active PNF after the addition of phosphorus (Arenovski et al. 1995). Havskum \& Riemann (1996) also noted that PNF were responsible for $86 \%$ of the entire nanoflagellate bac-

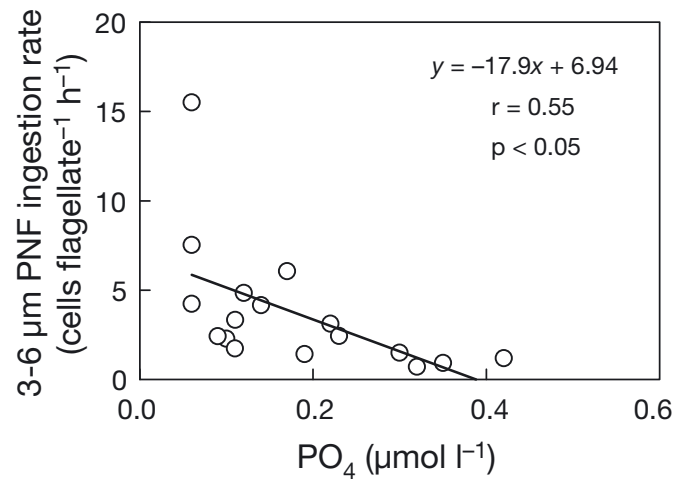

Fig. 9. Relationship between $\mathrm{PO}_{4}$ concentrations and ingestion rates of 3-6 $\mu \mathrm{m}$ pigmented nanoflagellates (PNF) 
terivory in surface water with low inorganic nutrient concentration $\left(<0.1 \mu_{\mathrm{mol} \mathrm{l}}^{-1}\right)$, while below the pycnocline, where nutrients were present at higher concentrations, PNF accounted for only $19 \%$ of the nanoflagellate bacterivory. Together, these findings strongly support our results that the mixotrophic PNF use their feeding ability to supply themselves with phosphorus when concentrations of dissolved $\mathrm{P}$ are low during the warmer season. However, it is noteworthy that acquisition of nutrients is only one of several possible inducements of phagotrophic behavior among PNF species. Mixotrophy can be observed even when nutrients are high. For example, Hall et al. (1993) measured high rates of bacterivory by PNF in coastal waters during an upwelling event when nitrogen and phosphorus concentrations were high. All of these results advocate for a conceptual integration of PNF into the discussion of plankton nutrient limitation.

Information about grazing on bacteria by different sizes of HNF and PNF is still limited for marine systems, and our data contribute to furthering the understanding of the structure and functioning of microbial food webs in coastal marine environments. This study identified $<6 \mu \mathrm{m} \mathrm{HNF}$ (44\% grazing effect) and 3-6 $\mu \mathrm{m}$ PNF (52\% grazing effect) as the major grazers of bacteria in the coastal water of the subtropical western Pacific. Thus, mixotrophic grazing on bacteria may play a critical role in the utilization of energy and nutrients within the microbial food web in these coastal waters.

Acknowledgements. This study was supported by the grant (NSC 97-2917-I-564-153 and NSC-98-2611-M-019-021-MY3) from the National Science Council, ROC.

\section{LITERATURE CITED}

Almeida MA, Cunha MA, Alcântara F (2001) Loss of estuarine bacteria by viral infection and predation in microcosm conditions. Microb Ecol 42:562-571

> Arenovski AL, Lim EL, Caron DA (1995) Mixotrophic nanoplankton in oligotrophic surface waters of the Sargasso Sea may employ phagotrophy to obtain major nutrients. J Plankton Res 17:801-820

Berninger UG, Finlay BJ, Kuuppo-Leinikki P (1991) Protozoan control of bacterial abundances in freshwater. Limnol Oceanogr 36:139-147

Berninger UG, Caron DA, Sanders RW (1992) Mixotrophic algal in three ice-covered lakes of the Pocono mountains, U.S.A. Freshw Biol 28:263-272

Bird DF, Kalff J (1986) Bacterial grazing by planktonic lake algae. Science 231:493-494

Caron DA, Sanders RW, Lim EL, Marrase C and others (1993) Light-dependent phagotrophy in the freshwater mixotrophic chrysophyte Dinobryon cylindricum. Microb Ecol 25:93-111

> Chan YF, Tsai AY, Chiang KP, Hsieh CH (2009) Pigmented nanoflagellates grazing on Synechococcus: Seasonal variations and effect of flagellate size in the coastal ecosystem of subtropical western Pacific. Microb Ecol 58:548-557
Choi JW (1994) The dynamic nature of protistan ingestion response to prey abundance. J Eukaryot Microbiol 41: 137-146

Christaki U, Wambeke FV, Dolan JR (1999) Nanoflagellates (mixotrophs, heterotrophs and autotrophs) in the oligotrophic eastern Mediterranean: standing stocks, bacterivory and relationships with bacterial production. Mar Ecol Prog Ser 181:297-307

Christaki U, Giannakourou A, Wambeke FV, Gregori G (2001) Nanoflagellate predation on auto- and heterotrophic picoplankton in the oligotrophic Mediterranean Sea. J Plankton Res 23:1297-1310

Cleven EJ, Weisse T (2001) Seasonal succession and taxonspecific bacterial grazing rates of heterotrophic nanoflagellates in Lake Constance. Aquat Microb Ecol 23: $147-161$

Currie DJ, Kalff J (1984) A comparison of the abilities of freshwater algal and bacteria to acquire and retain phosphorus. Limnol Oceanogr 29:298-310

Dolan JR, Šimek K (1998) Ingestion and digestion of an autotrophic picoplankton, Synechococcus, by a heterotrophic nanoflagellate, Bodo saltans. Limnol Oceanogr 43: 1740-1746

Epstein SS, Shiaris MP (1992) Size-selective grazing of coastal bacterioplankton by natural assemblages of pigmented flagellates, colorless flagellates, and ciliates. Microb Ecol 23:211-225

Fuhrman JA, Noble RT (1995) Viruses and protists cause similar bacterial mortality in coastal seawater. Limnol Oceanogr 40:1236-1242

Gong GC, Liu KK, Pai SJ (1995) Prediction of nitrate concentration from two end member mixing in the Southern East China Sea. Deep-Sea Res I 15:827-842

González JM, Torréton JP, Dufour P, Charpy L (1998) Temporal and spatial dynamics of the pelagic microbial food web in an atoll lagoon. Aquat Microb Ecol 16:53-64

- Hall JA, Barrett DP, James MR (1993) The importance of phytoflagellate, heterotrophic flagellate and ciliate grazing on bacteria and picophytoplankton size prey in a coastal marine environment. J Plankton Res 15:1075-1086

> Havskum H, Riemann B (1996) Ecological importance of bacterivorous, pigmented flagellates (mixotrophs) in the Bay of Aarhus. Mar Ecol Prog Ser 137:251-263

> Hitchman RB, Jones HLJ (2000) The role of mixotrophic protists in the population dynamics of the microbial food web in a small artificial pond. Freshw Biol 43:231-241

> Holen DA (1999) Effects of prey abundance and light intensity on the mixotrophic chrysophyte Poterioochromonas malhamensis from a mesotrophic lake. Freshw Biol 42: 445-455

$>$ Hwang SJ, Heath RT (1999) Zooplankton bacterivory at coastal and offshore sites of the Lake Erie. J Plankton Res 21:699-719

> Ichinotsuka D, Ueno H, Nakano S (2006) Relative importance of nanoflagellates and ciliates as consumers of bacteria in a coastal sea area dominated by oligotrichous Strombidium and Strobilidium. Aquat Microb Ecol 42:139-147

James MR, Hall JA, Barrett DP (1996) Grazing by protozoa in marine coastal and oceanic ecosystems off New Zealand. NZ J Mar Freshw Res 30:313-324

> Jezbera J, Nedoma J, Šimek K (2003) Longitudinal changes in protistan bacterivory and bacterial production in two canyon-shaped reservoirs of different trophic status. Hydrobiologia 504:115-130

Jones RI (1994) Mixotrophy in planktonic protists as a spectrum of nutritional strategies. Mar Microb Food Webs 8: $87-96$ 
Jones RI, Rees S (1994) Characteristics of particle uptake by the phagotrophic phytoflagellate, Dinobryon divergens. Mar Microb Food Webs 8:97-110

> Jürgens K, Güde H (1990) Incorporation and release of phosphorus by planktonic bacteria and phagotrophic flagellates. Mar Ecol Prog Ser 59:271-284

> Jürgens K, Šimek K (2000) Functional response and particle size selection of Halteria cf. grandinella, a common freshwater oligotrichous ciliate. Aquat Microb Ecol 22: $57-68$

Kisand V, Zingel P (2000) Dominance of ciliate grazing on bacteria during spring in a shallow eutrophic lake. Aquat Microb Ecol 22:135-142

Landry MR, Lehner-Fournier JM, Sundstrom TA, Fugerness UL, Selph KE (1991) Discrimination between living and heat-killed prey by a marine zooflagellate Paraphysomonas vestita (Stokes). J Exp Mar Biol Ecol 146: 139-151

Lin YC, Tsai AY, Chiang KP (2009) Trophic coupling between Synechococcus and pigmented nanoflagellates in the coastal waters of Taiwan, western subtropical Pacific. J Oceanogr 65:781-789

- McManus GB, Okubo A (1991) On the use of surrogate food particles to measure protistan ingestion. Limnol Oceanogr 36:613-617

Medina-Sánchez JM, Villar-Argaiz M, Carrillo P (2004) Neither with nor without you: a complex algal control on bacterioplankton in a high mountain lake. Limnol Oceanogr 49:1722-1733

> Moorthi S, Berninger UG (2006) Mixotrophic nanoflagellates in coastal sediments in the western Baltic Sea. Aquat Microb Ecol 45:79-87

Moorthi SD, Caron DA, Gast RJ, Sanders RW (2009) Mixotrophy: a widespread and important ecological strategy for planktonic and sea-ice nanoflagellates in the Ross Sea, Antarctica. Aquat Microb Ecol 54:269-277

> Nakano S, Ishii N, Manage PM, Kawabata Z (1998) Trophic roles of heterotrophic nanoflagellates and ciliates among planktonic organisms in a hypereutrophic pond. Aquat Microb Ecol 16:153-161

> Nygaard K, Tobiesen A (1993) Bacterivory in algae: a survival strategy during nutrient limitation. Limnol Oceanogr 38: 273-279

Pace ML, McManus GB, Findlay SEG (1990) Planktonic community structure determines the fate of bacterial production in a temperate lake. Limnol Oceanogr 35:795-808

Parsons TR, Maita Y, Lalli CM (1984) A manual of chemical and biological methods for seawater analysis. Pergamon Press, Oxford

Porter KG, Feig YS (1980) The use of DAPI for identifying and counting aquatic microflora. Limnol Oceanogr 25:943-948

Probyn TA, Waldron HN, James AG (1990) Size-fractionated measurements of nitrogen uptake in aged upwelled waters: implications for pelagic food web structures. Limnol Oceanogr 35:202-210

Rassoulzadegan F, Laval-Pento M, Sheldon RW (1988) Partitioning of the food ratio of marine ciliates between picoand nanoplankton. Hydrobiologia 159:75-88

Safi KA, Hall JA (1999) Mixotrophic and heterotrophic nanoflagellate grazing in the convergence zone east of New Zealand. Aquat Microb Ecol 20:83-93

Salonen W, Jokinen S (1988) Flagellate grazing on bacteria in a small dystrophic lake. Hydrobiologia 161:203-209

Sanders RW, Porter KG, Bennett SJ, Debiase AE (1989) Seasonal patterns of bacterivory by flagellates, ciliates, roti- fers, and cladocerans in a freshwater planktonic community. Limnol Oceanogr 34:673-687

Sanders RW, Berninger UG, Lim EL, Kemp PF, Caron DA (2000) Heterotrophic and mixotrophic nanoflagellate predation on picoplankton in the Sargasso Sea and Georges Bank. Mar Ecol Prog Ser 192:103-118

Sanders RW, Caron DA, Davidson JM, Dennett MR, Moran DM (2001) Nutrient acquisition and population growth of a mixotrophic alga in axenic and bacterized cultures. Microb Ecol 42:513-523

Sherr BF, Sherr EB, Fallon RD (1987) Use of monodispersed fluorescently labeled bacteria to estimate in situ protozoan bacterivory. Appl Environ Microbiol 53:958-965

Sherr EB, Sherr BF (2002) Significance of predation by protists in aquatic microbial food webs. Antonie van Leeuwenhoek 81:293-308

Sherr EB, Sherr BF, McDaniel J (1991) Clearance rates of $<6 \mu \mathrm{m}$ fluorescently labeled algae (FLA) by estuarine protozoa: potential grazing impact of flagellates and ciliates. Mar Ecol Prog Ser 69:81?92

> Sime-Ngando T, Demers S, Juniper SK (1999) Protozoan bacterivory in the ice and the water column of a cold temperate lagoon. Microb Ecol 37:95-106

Šimek K, Straškrabová V (1992) Bacterioplankton production and protozoan bacterivory in a mesotrophic reservoir. J Plankton Res 14:773-787

Taira Y, Uchimiya M, Kudo I (2009) Simultaneous estimation of viral lysis and protozoan grazing on bacterial mortality using a modified virus-dilution method. Mar Ecol Prog Ser 379:23-32

Thingstad TF, Havskum H, Garde K, Riemann B (1996) On the strategy of 'eating your competitor': a mathematical analysis of algal mixotrophy. Ecology 77:2108-2118

Tsai AY, Chiang KP, Chang J, Gong GC (2005) Seasonal diel variations of picoplankton and nanoplankton in a subtropical western Pacific coastal ecosystem. Limnol Oceanogr 50:1221-1231

Tsai AY, Chiang KP, Chan YF, Lin YC, Chang J (2007) Pigmented nanoflagellates in the coastal western subtropical Pacific are important grazers on Synechococcus populations. J Plankton Res 29:71-77

Tsai AY, Chiang KP, Chang J, Gong GC (2008) Seasonal variations in trophic dynamics of nanoflagellates and picoplakton in coastal waters of the western subtropical Pacific Ocean. Aquat Microb Ecol 51:263-274

> Unrein F, Massana R, Alonso-Sáez L, Gasol JM (2007) Significant year-round effect of small mixotrophic flagellates on bacterioplankton in an oligotrophic coastal system. Limnol Oceanogr 52:456-469

Urabe J, Gurung TB, Yoshida T (1999) Effect of phosphorus supply on phagotrophy by the mixotrophic alga Uroglena americana (Chrysophyceae). Aquat Microb Ecol 18:77-83

Vaqué D, Pace ML (1992) Grazing on bacteria by flagellates and cladocerans in lakes of contrasting food-web structure. J Plankton Res 14:307-321

Vaqué D, Gasol JM, Marrasé C (1994) Grazing rates on bacteria: the significance of methodology and ecological factors. Mar Ecol Prog Ser 109:263-274

Vaqué D, Guadayol O, Peters F, Felipe J and others (2008) Seasonal changes in planktonic bacterivory rates under the ice-covered coastal Arctic Ocean. Limnol Oceanogr 53:2427-2438

Zubkov MV, Tarran GA (2008) High bacterivory by the smallest phytoplankton in the North Atlantic Ocean. Nature 455:224-226 